\title{
The trade union right to organise and its exercise in the Republic of Macedonia
}

\begin{abstract}
The right to form trade unions is provided by the Universal Declaration of Human Rights and other international documents adopted under the regulatory systems of the United Nations, the European Social Charter and ILO Conventions No. 87 and 98. The constitution of the Republic of Macedonia has implemented this right in the legal system of the Republic, regulating it in detail by the Law on Labour Relations and other laws, as well as by a number of collective agreements. Normative regulations concerning organising in the Republic are comprehensive and made according to international and European standards but, in practice, they are inconsistently applied. This has resulted in a denial of the right of workers to form trade unions and join them, the obstruction of trade union representatives, and a poor functioning of the system of trade union protection, etc. Concerning the relationship between trade unions and the government, the general impression is that trade unions are very close to the government and are under-active in protecting workers' rights.
\end{abstract}

Keywords: labour law instruments, trade unions, workers, organising, ILO Conventions, collective agreements, collective institutions, courts, legalisation of $I R$, union involvement in politics, labour inspectorates

Introduction

Trade unions are a socio-economic organisation of workers who unite them in the struggle primarily for the realisation of their economic interests. They, at a historical stage in the struggle for workers' rights arose in the early nineteenth century as a reflection and result of deep contradictions in the capitalist mode of production. The first trade unions were a reflection of the efforts of wage-workers to join together in stable and independent organisations to protect themselves from the worst forms of capitalist exploitation. The emergence of trade unions represents a phase of the labour movement in which workers constitute an independent social class. This is the stage of the class struggle in which a significant part of wage-workers, as a result of their own daily experience, become aware of the contradictions between the interests of workers and employers and that, only with joint effort and solid workers' organisations can they resist the pressure resulting from employers' oppression. This is the stage in which the working class transforms itself from a 'class by itself' into 'a class of its own'.

1 A version of this article including references in Macedonian is available from the authors. 
In the early stages of development, trade unions, in most cases, gathered in their ranks only middle-class workers made up of better-paid skilled and highly-skilled workers. Only at the end of the ninetieth century, was there a gradual 'opening' of trade unions to the less-paid and less-skilled layers of the working class.

In the modern world, trade unions represent the most extensive form of workers' self-organising. Today, trade unions exist in almost all countries. Their primary task, and the raison d'être of their existence is the struggle for the realisation and defence of the economic interests of workers. In addition to these basic functions, trade unions have themselves emerged as a factor in politics, culture and education. In many countries, they often directly or indirectly, in co-operation with labour parties participate actively in political life. In recent times, they have increasingly entered into political arrangements with bourgeois parties.

Viewed from a legal point of view, the formation of trade unions is an expression of the right to freedom of association. This right is one of the primary means of the expression of citizens' political and socio-economic activities and, via its use as a means of the expression of socio-economic activities, trade unions were formed as organisations for the defence and protection of the interests and rights of wage-workers.

The right to join a trade union, as well as the right to freedom of association, is subject to the regulation of a number of international legal acts on human rights including:

- the Universal Declaration of Human Rights

- the International Covenant on Economic, Social and Cultural Rights

- the International Covenant on Civil and Political Rights

- the Convention on the Protection of Human Rights and Fundamental Freedoms (the European Convention on Human Rights)

- the European Social Charter and ILO Conventions No. 87 and 98.

The basic idea of the right of citizens to form trade unions in the Republic of Macedonia, by skilled use of the precise formulation of constitutional legal norms, has been implemented in the constitution of the Republic. They are elaborated in the Law on Labour Relations and the collective agreements which regulate social relationships in various fields of work, as well as in other laws that contain provisions on the legal status of certain categories of citizens employed in the various organs and institutions of the Republic, such as the Law on Civil Servants; the Law on Public Servants; the Law on Service in the Armed Forces; the Law on Internal Affairs; the Law on the Police; and others.

The constitution and laws of the Republic of Macedonia regulate union organising according to the standards contained in the international legal documents on human rights. Thus, they contain a solid legal basis for the establishment of trade unions which are efficient and effective at protecting the rights and interests of workers in the Republic. However, similar to all countries in transition, the constitution and laws are not enforced consistently in practice, which leads to a discrepancy between the law and the reality in social relations. Concerning the right to organise in the Republic and the protection of workers' rights, there is a substantial discrepancy between the norms contained in the laws and collective agreements and the actual state of affairs. 
The trade union movement in the Republic of Macedonia is fragmented, with a number of trade unions with different programmes and political orientations. This significantly weakens the strength of the movement. Employers often do not respect unions' right to organise workers, making it difficult to protect workers' rights, and pressure unionised workers in order to force them to give up their union activities and drop their membership. Therefore, a considerable number of workers have a fear of the consequences of trade union membership and of union activity, which prevents union activities and union protection of workers' rights and interests. Furthermore, bureaucratic union leaders do not have sufficient sensitivity to the needs of members and lack the means to organise trade union activities, which weakens the effectiveness of unions in protecting workers' rights and interests. The connection of trade union leaders with ruling groups in the state is a throwback to the past, one-party system and leads to a weakening of the confidence of workers in the unions and in their willingness to protect their rights. This further leads to a high degree of indifference of workers towards joining a trade union.

\section{The right to organise in international human rights documents}

The Universal Declaration of Human Rights contains very brief provisions on the right to freedom of association, both in general and in the socio-economic field. The latter provision is contained in Article 20 of the Declaration and allows the formation of trade unions as organisations for the protection of the rights of labourers. Paragraph 2 of this Article contains a provision on the prohibition of forced mergers, as well as a prohibition on forcing workers to join a trade union.

The International Covenant on Economic, Social and Cultural Rights, a function of the more detailed regulation of human rights contained in the Universal Declaration of Human Rights, contains in Article 8 very precise provisions on workers' unions. According to the provisions of Paragraph 1, Sub-paragraph (a) of this Article, states who are parties to the Covenant should ensure the right of every person to form, with other people, and join a trade union of their choice, only according to the rules that determine the most appropriate organisation with the aim of protecting and improving their economic and social interests. The exercise of this right may be subject only to limitations prescribed by law and which are necessary in a democratic society in the interests of national security or public order, or for the protection of the rights and freedoms of others. The provisions of Sub-paragraph (c) of the same Article stipulate the right of trade unions to conduct their activities freely, without any restrictions, other than those previously listed. These provisions do not, however, prevent the state from regulating legal limits to this right concerning members of the armed forces, police officers and public servants.

The International Covenant on Civil and Political Rights stipulates the right to organise in provisions contained in Article 22, Paragraphs 1 and 2, as an element of the right to freedom of association. Concerning the limitation of states' abilities to restrict the application of this right, this pact is a little more generic than the previous one: thus, Article 22, Paragraph 2 of the Covenant provides that the exercise of this right may be subject to limitations, in addition to the reasons expressed above and for reasons of public safety, the protection of public health or morals. 
The European Convention on Human Rights stipulates unions' right to organise in its Article 11, Paragraph 1 and 2, and in the same manner as the International Covenant on Civil and Political Rights.

The European Social Charter stipulates the right to organise in provisions contained in Article 5. These provisions include the objectives of national legislation on the organising of workers into unions, i.e. improving and guaranteeing workers' freedom to organise themselves in local, national and international organisations in order to protect their economic and social interests. States are entitled to their own laws limiting the right to form trade unions as regards members of the armed forces and the police. Civil servants, as the subject of legal restrictions, are not mentioned in this Article.

Convention No. 87 of the International Labour Organization (ILO) is dedicated to workers' and employers' right to freedom of association and the protection of the right to organise. Its provisions elaborate in a more detailed way those of the International Covenant on Economic, Social and Cultural Rights on the right of workers to join a trade union and to protect their interests. The Convention makes no reference to the trade union organising of workers. However, there is no doubt that it applies to such organisations because it is an element of the right to freedom of association.

ILO Convention No. 98, which is dedicated to the right to organise and to make collective agreements, dating from 1949, does contain specific provisions on the right to form trade unions, unlike Convention No. 87. Thus, by Article 1, Paragraph 1, it guarantees workers the right to protection against anti-union discrimination in relation to their employment. Paragraph 2 of this Article provides that such protection should be applied, in particular, in relation to decisions related to the conditioning of employment offers on not joining, or leaving, a union, as well as cases of dismissal for reasons related to membership of trade unions or participation in union activities outside working hours or, with the consent of employers, within working hours.

The Convention prohibits all activities that aim to promote the establishment of workers' organisations that would in any way be under the domination of employers, as well as those aimed at supporting labour trade unions with financial or other assets with the aim of putting these organisations under the control of employers or their organisations.

Article 3 of the Convention obliges states parties to comply with national requirements and to establish appropriate mechanisms to ensure respect for the right to organise trade unions as defined by the above provisions.

The right to trade union organising in the Constitution, laws and collective agreements in the Republic of Macedonia

Article 20 of the Constitution of the Republic of Macedonia contains general provisions on citizens' rights to freedom of association in order to achieve and protect their political, economic, social, cultural and other rights and beliefs, while specific provisions on the right to form trade unions are contained in Article 37. According to these provisions, citizens have the right to form trade unions, in order to achieve their economic and social rights. Trade unions can form federations and be members of international trade union organisations. The law may, however, place limits on the exercise 
of trade union rights in the armed forces, the police and among administrative authorities.

There is little doubt that the most comprehensive and, thus, the most important provisions on the trade union organising of workers in the Republic of Macedonia are those which are contained in the Law on Labour Relations.

According to Article 184 of the Law, workers have a discretionary right to form a trade union, and to join one, under conditions prescribed by the statute and the rules of the union. A trade union is defined as a democratic and independent workers' organisation with which a worker voluntarily associates in connection with the advocacy, representation, promotion and protection of their economic, social and other individual and collective interests.

Article 185 of the Law prohibits discrimination in terms of where workers are put at a disadvantage because of their membership, or non-membership, of a trade union or because of their participation, or non-participation, in union activities.

A trade union cannot be dissolved or suspended from its activities by administrative means if it is established and is performing its work in accordance with the Law. The activities of trade unions and their representatives cannot be restricted by employers as long as they comply with the law and with collective agreements (Article 186).

Trade unions can form federations or other forms of association in order to join their interests at a higher level. These forms of association of trade unions enjoy all the rights and freedoms of trade unions. Trade unions have the right freely to associate and to co-operate with international organisations established for the exercise of their rights and interests (Article 187).

The Law on Civil Servants of the Republic of Macedonia (Article 26) stipulates that civil servants, in order to achieve their economic and social rights, have the right to form trade unions and join them under the terms and conditions established by statute. Thus, the Law contains no restrictions on the exercise of the trade union rights of civil servants despite the Constitution prescribing the possibility of such restrictions.

Completely identical provisions on the right to form trade unions are contained in Article 30 of the Law on Public Servants.

According to Article 49 of the Defence Law, members of the Army of the Republic of Macedonia are prohibited from forming trade unions, but only in situations of war and emergency.

The laws in the field of internal affairs which regulate the rights and duties of employees in this area (the Law on Internal Affairs and the Law on the Police) do not contain provisions on union organising, this being left to the collective agreement signed by the Ministry of Internal Affairs with the Macedonian Police trade union. The provisions of this agreement, in terms of regulating the trade union rights of workers in internal affairs, do not in essence differ from the provisions contained in the General Collective Agreement on the Public Sector, except in respect of some specific features arising from the organisational set-up of the Ministry and its material and technical capabilities that are of relevance to the work of trade union representatives and their communication with the employer. 
This General Collective Agreement, which regulates the rights and obligations of workers and employers in public sector employment (state authorities, public institutions, departments, agencies and other organisations in law in the public sector who employ workers and are financed from the Budget), requires employers to establish appropriate conditions for the carrying out of the activities of trade unions concerning the protection of the rights of employees, as established by the law and in collective agreements. The activity of a trade union and its representatives cannot be restricted in the sphere of employment. At the request of the trade union, the employer should provide information on those issues that have an impact on, or influence most directly, the material and social position of workers. The employer should also respect the opinions and proposals of trade unions in the decision-making process and their proposed solutions on issues having a significant impact on the financial and social status of workers, or on the exercise of their rights. The representatives of the trade union must be allowed unhindered lines of communication with the employer, or other authorised person; and with union members in the employer's institution when necessary as regards the functioning of the trade union.

The employer must also allow union activity and seamless communications with authorised trade union representatives from higher levels of trade union organisation that are not employed by the employer.

The employer is obliged to provide space and certain professional, administrative and technical requirements for the exercise of the functions of trade unions and trade union representatives. Trade union representatives enjoy special protection and cannot be held responsible for carrying out trade union activities in accordance with the law and the collective agreement, or be put in a less favourable position, including the termination of their employment. There are special protections for trade union representatives during the period of their mandates as well as for two years after their expiry.

The General Collective Agreement for the Private Sector, or the General Collective Agreement for the Economy of the Republic of Macedonia, which is its official name, contains provisions for union workers that are slightly different from the provisions of the General Collective Agreement for the Public Sector. Most evident are the provisions of Article 58 which prohibit employers forcing union representatives into periods of paid leave, or being sent to other jobs without their consent, and from making decisions on the termination of their employment due to business reasons which are not specified in the contract. There is no doubt that this refers to trade union activity in accordance with the Law and the collective agreement.

Provisions on trade union organising are also contained in the collective agreements signed in certain branches of the economy - the so-called sectoral collective agreements - such as the Collective Agreement for the Agricultural and Food Processing Industry; the Collective Agreement for the Textiles Industry; the Collective Agreement for the Chemicals Industry; the Collective Agreement for Hotel Activities; as well as other collective agreements. In these collective agreements, the provisions on trade union organising contained in the General Collective Agreement for the Private Sector are generally taken into account, to which provisions others may be added which arise from the particularities of work carried out in the relevant industries. 


\section{Pathologies in the exercise of the right to organise in the Republic of Macedonia}

The exercise of trade union rights in the Republic of Macedonia is loaded with a number of socio-pathological phenomena.

At the forefront is the fragmentation of the trade union movement, which is split into a number of trade unions, weakening the power of the movement because this makes it fissured and disconnected. The power of social action, and thus the union movement as a deliverer of social action is, among other things, directly proportional to the number of people who comprise it. These may be unique, organised in a unique organisational system or divided into multiple systems. There is no doubt that the same number of people organised into a single system gives greater power, and thus greater force of action, than the same number of people in a number of disparate organisational systems.

In the Republic of Macedonia, there are four national trade unions. These are: the Union of Trade Unions of Macedonia; the Confederation of Free Trade Unions; the Union of Independent and Autonomous Trade Unions; and the Confederation of Trade Union Organisations of Macedonia. These organisations are fragmented into a number of sectoral organisations, as well as independent and autonomous trade unions, whose number, according to the register of trade unions held by the Ministry of Labour and Social Policy is 36. For small Macedonia, with about 900000 people fit for work, of which two-thirds are employed, that is, without a doubt, a large number.

Between trade unions at the national level, and often between individual trade unions in different constellations of them, disagreements and conflicts occur about the unionisation of workers as well as about the ways and methods of trade union action. This weakens the power of collective action and reduces its efficiency in protecting the rights and interests of workers.

Secondly, no less harmful a pathology in Macedonia's trade union movement is the disregard of employers for the trade union rights of workers. Employers do not allow workers to join a union, or threaten workers with dismissal if they do not cancel their union activities. The latest example of this dates from mid-September 2012, via the threat of the Minister of Health, Nikola Todorov, to doctors employed in public health institutions that had responded to the trade union's strike call made with the aim of protecting workers' rights on the means of accounting and on the payment of their monthly salaries. Furthermore, some employers seek legal intervention to interfere with the exercise of trade union activities in the protection of workers. In firm connection with this is the lawsuit of the Ministry of Health against the strike action taken by the Clinical Trade Union, due to the claimed immediate threat to the life and health of the citizens, and seeking the imposition of basic court action to prohibit the strike as well as an interim measure aimed at securing the postponement of the strike pending a final court decision. This is the first time in the history of the Macedonian trade union movement, whose origins date back to the first decade of the twentieth century, that the government has sought to sue a trade union on the grounds of its union activities.

The result of such an approach by employers is that workers are afraid to enter union membership and often avoid union activities. For the same reason, they often do not 
support the union in the work of the collective protection of workers' rights and do not co-operate with them.

The bureaucratisation of the trade union leadership is an old ailment in most European Union countries, including in the Republic of Macedonia. In many cases in the trade unions, there is a thin layer of professional union managers in whose hands are concentrated extraordinarily high, often informal, levels of authority and power which has enabled them to transform internal democracy into a mere formality and, in fact, to take over the real management of the trade union. This internal development, in many trade unions, leads to substantial differences in the relationship between management and members, which leads to tensions and to factions within the trade union, as well as to conflict between management and membership, and between factions which are usually led by bureaucratic trade union leaders who are often estranged from the membership. This often leads to the splitting of the trade union into smaller organisations which weakens its power and the strength of the trade union struggle. Thus, in 2005 there was a conflict between a President of the Union of Trade Unions of Macedonia, who was a professional trade union leader, and a President of the Trade Union of Education, Science and Culture, which was part of the same union confederation. The consequence of this conflict was the demerger of the Trade Union of Education, Science and Culture from the Union of Trade Unions and its transformation into an independent trade union.

A bureaucratic trade union leadership is not interested in the concerns and needs of union members. Alienated from the membership, they are hungry for power and dominance, and are often associated with the ruling political groups in the Republic of Macedonia, thus providing themselves with formal authority and power in society. However, to the extent that their authority is higher, so this is lower within the ranks of the working class, because workers do not trust a union that flirts and co-operates with a government which, in turn, is concerned apparently with protecting the interests of capital, created after all from the surplus value of workers.

In 1940, just before liquidation in Mexico by Stalin's agents, Trotsky wrote that the approximation of the trade unions to state power and their co-operation with it represents the greatest decadence of the trade union movement and a circumvention of the rights of workers.

In truth, there are brave trade union organisations that are firmly on the side of wage-workers. Even so, these are rare meteorites on the scene of the Macedonian trade union movement and their struggle becomes significantly weakened or suppressed by the action-mindsets of pro-government trade unions. Such was the case with the Clinical Trade Union in the summer of 2012, which firmly sided with the doctors in their struggle against the new system of the calculation and payment of their monthly salaries and other benefits. However, a new doctors trade union soon appeared which had been formed expressly to side with the government, supporting its struggle against the rebellious trade union. Other trade unions more or less passively watched the trade union struggle of disempowered doctors against the power of the state and its organs.

Thus it came about that, in 2012, Macedonian trade unions experienced the greatest year of decadence in their hundred year-long history, as a result of their passivity and reticence which, in turn, stems from their undignified attachment to power. In contrast, 
they should be defending the rights of workers against this, because it evidently protects the interests of employers and primarily those who own sizable amounts of capital.

These latest developments in Macedonia's trade union movement confirms the correctness of the view that trade unions should be politically neutral. They should never be tied to a political party, because parties protect their own political interests, while trade unions should be protecting the economic interests of their members. Political and economic interests do not always coincide. Trade unions may support the platform of a particular political party, where this is in accordance with the interests of workers, but only for as long as this remains the case, and not permanently, because a lasting attachment to a political party means the political incorporation of trade unions which, dialectically, cannot and must not be political parties.

\section{Conclusion}

The right to form trade unions is an element of workers' rights of association. It is a reflection of the human qualities that seek to live and work in community with other people; a human being is, as Aristotle said, zoon politikon, i.e. a social animal.

Trade union organisation is an urgent need of workers in their struggle against employers in whose hands lies capital and, therefore, social power. Workers do not have capital, but they do have their numbers and a quantity of will aimed at protecting the rights and interests of workers, and can achieve significant results in the improvement of the economic position of the working class. This calls for the greatest possible unification and homogenisation of the trade union movement in order to increase the effectiveness of trade union action in the struggle for the protection of the rights and interests of workers against employers.

Workers and employers, through the lenses of sociology and social psychology, are two opposing, antagonistic social groups. Employers make capital from the surplus value generated by workers. Their interest is in earning as much as possible with the least expenditure of money, creating capital. The desire to make money at the lowest levels of expenditure is the basic cause of the exploitation of wage-workers by employers.

In contrast, workers have an interest in obtaining the greatest possible benefits from work - the best possible working conditions; higher salaries; longer daily and weekly rest breaks; and better annual holidays - and thus, of course, at the expense of the employer's capital account. In striving for these interests, they cannot fight alone, as isolated individuals, but unionisation puts them in a different situation. Thus, trade union organising is a natural need of workers arising directly from their social position. If workers' organisation into trade unions is a natural need, then the right to organise trade unions is also a natural right of workers.

The enormous increase in the size of the middle class, from whose ranks are recruited a large number of workers, led in the years following World War II to relations between employers, as owners of capital, and workers being humanised and regulated by a number of international human rights documents. The right to organise a trade union, as a human right among other such rights, is a subject of regulation by various international legal documents on human rights, among them the Universal Declaration of Human Rights; the International Covenant on Economic, Social and Cultural Rights; 
the International Covenant on Civil and Political Rights; the Convention for the Protection of Human Rights and Fundamental Freedoms (the European Convention on Human Rights); the European Social Charter; and ILO Conventions 87 and 98.

The provisions of these acts on workers' organising into trade unions have been implemented in the Constitution of the Republic of Macedonia and in the Law on Labour Relations and other laws of the Republic, as well as in collective agreements. The normative regulations on workers' organisation in the Republic of Macedonia contained in these acts, despite being inclined more to the interests of employers than to the interests of workers, guarantee workers a basically efficient and effective exercise of their rights to organisation.

However, in the context of the huge level of unemployment in the Republic of Macedonia, with one-third of the total number of citizens of working age being out of work, employers often grossly violate the rights of workers, interfering with and preventing trade union organising and frequently blackmailing workers with the threat of being laid-off.

The Macedonian trade union movement is highly fragmented into many trade unions, grouped into no fewer than four national trade union organisations. Disputes and conflicts over the ways and methods of trade union action often arise between the unions. A large number of unions flirt with the parties in power or openly support the government which, in these conditions, usually protects employers because it depends on their revenues. The government, applying the principle of 'divide and rule' and supporting the fragmentation of the trade union movement, has even encouraged it by expressly forming new trade unions sympathetic to it, providing it with an easy means of silencing and becalming those rare trade unions, such as the Clinical Trade Union, which are capable of taking an independent stance.

Trade union leaders are frequently bureaucratic and estranged from the members in whose name they have been established to serve. In such conditions, workers do not trust unions. The result is that the Macedonian trade union movement constitutes of about $30 \%$ of employed wage-workers who are, on the whole, very passive, with the exception of rare cases in which trade union activity is, nevertheless, mostly limited to participation in strikes and sparsely-attended trade union demonstrations along the streets of Skopje and other major Macedonian cities. Such a trade union cannot effectively and efficiently protect the rights and interests of workers.

An exit from this situation is very difficult to find. There is no doubt that the only way is to raise the class consciousness of workers, which can be achieved by a wellorganised and well-disposed trade union although, unfortunately, such does not exist in Macedonia. An important role in this direction could also be played by a labour party, or a left-oriented workers' and citizen's party, which also does not exist in Macedonia.

The obstruction of trade union organisation and trade union activity may be substantially prevented by the labour inspectorate of the Ministry of Labour and Social Policy. However, this is not an efficient process because workers are afraid to report the violation of their rights for fear of losing their jobs. Thus, Macedonian workers are poorly protected in the exercise of their constitutionally- and legally-guaranteed rights as well, of course, as in the exercise of their right to form trade unions which is a precursor to the achievement of other employment rights. 